\title{
Ørnfløya 1.
}

\section{En pionertidslokalitet fra tidlig eldre} steinalder på yttersida av Kvaløya i Troms

\begin{abstract}
During the past couple of decades both research projects and rescue excavations have contributed considerably to our understanding of the early Older Stone Age pioneer settlement along the entire Norwegian coast. However, understanding of the pioneers along the coast between northern Nordland and Finnmark counties is still rather limited. Excavations have largely taken place on sites within the middle and inner reaches of the fjord systems. The excavation of Ørnfløya 1 in 2013-14 offers new insights into the pioneer settlement on the outer coast facing the North Atlantic. The topographical and environmental settings of the site at the time of occupation are described, followed by a discussion of the excavation, chronology, raw material use, the artifacts, a possible dwelling, and the spatial organization of activities. The site is then interpreted in its regional, economic and settlement system setting, and in its national context.
\end{abstract}

\section{Innledning}

Forskningsprosjekt og forvaltningsutgravninger har gjennom de siste tiårene bidratt til en vesentlig økning i kunnskapen om steinalderens pionerbosetning (ca. 8800-6000 f.Kr.) langs Norskekysten (se for eksempel Breivik 2016; Nærøy 2015; Bang-Andersen 2018; Blankholm 2018a, b; Breivik og Bjerck 2018; Fretheim mfl. 2018; Kleppe 2018; Nyland 2018; Åstveit 2018). Det gjelder ikke minst tema som topografisk lokalisering, økonomi og bosetning. Både i Midt-, Vest- og Sørvest-Norge, men også i stor grad i Østlandsområdet, synes de tidlige pionerboplassene $i$ all vesentlighet å ha ligget langs ytterkysten (BangAndersen 2018; Breivik og Bjerck 2018; Damlien og Solheim 2018; Åstveit 2018). I Breivik og Bjercks studie (2018) av 244 lokaliteter i Midt-Norge fantes for eksempel hele 87 \% i det som den gang var skjærgården. Denne lokaliseringen forklares ofte med henvisning til kombinasjonen av en sterkt marint orientert økonomi og en høyproduktiv marin biotop (Breivik og Bjerck 2018). Dette bildet bør kanskje nyanseres noe. Ganske visst finner vi de fleste lokaliteter i de nevnte områder i skjærgården eller på gamle strandflater på yttersida, men det finnes også boplasser i andre topografiske soner og biotoper i disse regionene (BangAndersen 2018; Damlien og Solheim 2018). Opptellinger og rent numeriske sammenlikninger mellom topografiske soner og/eller regioner uten kildekritikk (se diskusjon i Breivik og Bjerck 2018) og grundig innsikt i ressursutnyttelsesmønstrene (Blankholm 2018b) sier lite.

Kontakt: Hans Peter Blankholm, E-post: hans.peter.blankholm@uit.no Institutt for arkeologi, historie, religionsvitenskap og teologi. UiT Norges arktiske Universitet. 
Går vi til Øst-Finnmark, hvor det finnes lite med skjærgård, synes situasjonen i alle fall å ha vært en annen. Her finner vi i hovedsak boplassene i fjordsystemene. Men hvordan var situasjonen i Troms, som hadde skjærgård så langt nord som i Nord-Troms?

Kunnskapen om pionertiden på selve yttersida av kysten mellom det nordlige Nordland og Finnmark er fortsatt svært begrenset. Forsknings- eller forvaltningsutgravninger av lokaliteter som Simavik (Sandmo 1986), Målsnes 1 (Blankholm 2008), Tønsnes havn (Finstad og Grydeland 2009; Skandfer mfl. 2010; Hood og Kjellman 2012; Gjerde og Hole 2013), Bergli (Grydeland og Arntzen 2010) og Stangnes syd (Nergaard og Oppvang 2014) har i all hovedsak vært rettet mot lokaliteter i de mellomste og indre fjordområdene. Pionertidens lokaliteter fra selve yttersida har riktignok vært kjent lenge (Sandmo 1986, 2011; Barlindhaug 1997), men bortsett fra Barlindhaugs (1994, 1997; se også Thuestad 2005) undersøkelse av Sandvika 1 har det inntil 2013 ikke vært foretatt utgravninger som har kunnet belyse slike lokaliteter nærmere.

Med utgravningen av Ørnflya 1, på yttersida av Kvaløya vest av Tromsø (se kart, figurene 1 og 2) i 2013-14 har vi fått et nytt bidrag til forståelsen av ovenstående tema i både regionalt og nasjonalt perspektiv. I det følgende beskrives først topografien, naturmiljøet og ressurstilgangen rundt Ørnfløya 1, slik det sannsynligvis var i pionertiden. Dernest diskuteres selve utgravningen, dateringen, råstoffbruken, oldsakene, de mulige sporene etter en bolig og romlig organisasjon av aktiviteter. Lokaliteten drøftes så i dens regionale, økonomiske og bosetningsmessige sammenheng samt nasjonale kontekst.

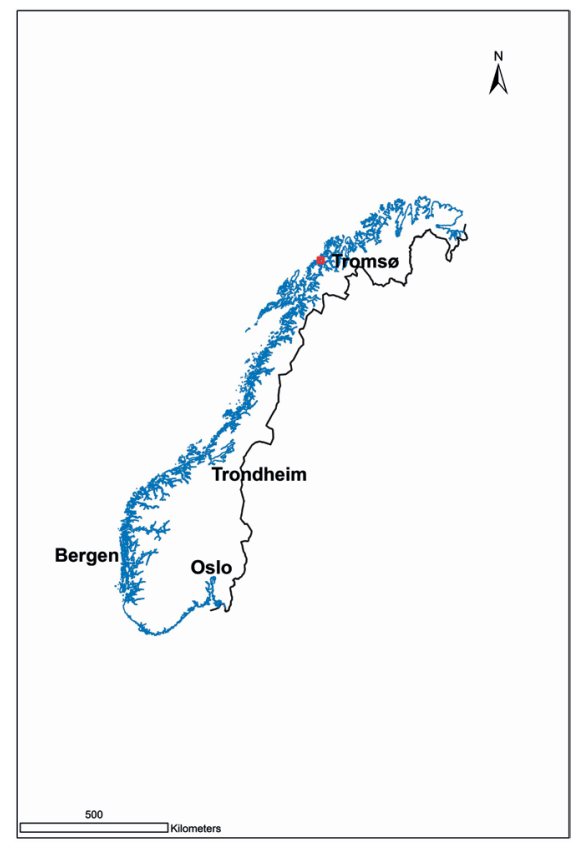

Figur 1. Kart over Norge med angivelse av studieområdet (rød firkant). Kartgrunnlag: Statens kartverk.

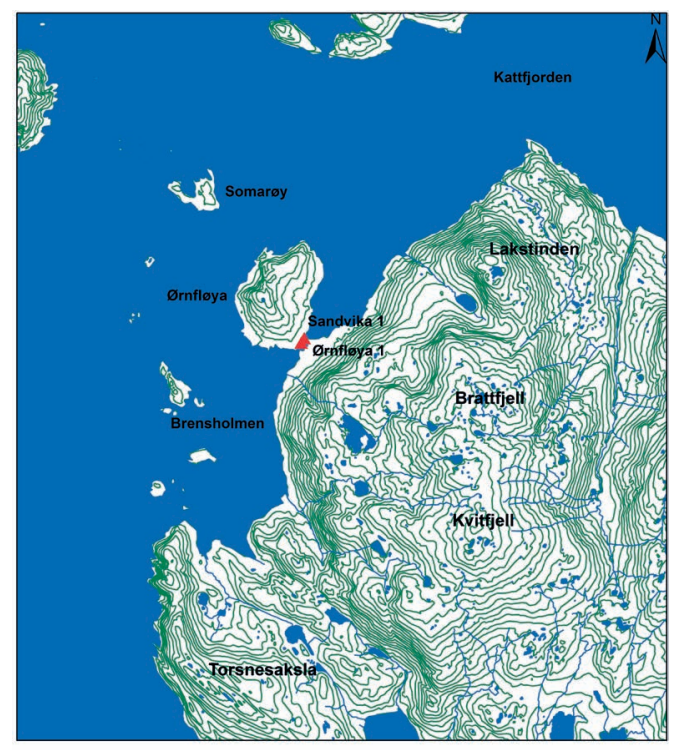

Kart over sørvestlige Kvaløya med ørnfløya 1 og Sandvika 1 markert med rød trekant. 1 Kilometers

Figur 2. Kart over den sørvestlige Kvaløya med Ørnfløya 1 og Sandvika 1 (røde trekanter) og slik topografien tok seg ut i tidlig pionertid. Kartgrunnlag: Statens kartverk. 


\section{Topografi, naturmiljo og ressurser}

Pionertidens boplasser synes i overveiende grad å ha vært strategisk lokalisert i landskapet ut fra kunnskap om god tilgang på mat og andre nødvendige ressurser, slik som råstoff til fremstilling av redskap, boliger, klær og liknende. Det har sannsynligvis vært mye variasjon i prioriteringene; noen ganger har kanskje maten vært det viktigste, andre ganger sosialt samvær, og man skal ikke undervurdere at også ønsket om markering overfor andre grupper, visuell kontroll over (nær)området eller religiøse faktorer kan ha spilt inn eller vært den viktigste årsak til beliggenheten.

Tilgangen på ressurser har i stort omfang vært betinget av de topografiske og andre naturmessige forhold, som klima, vegetasjon og årstid. Bosetningen og økonomien var, med få unntak, maritimt orientert. Langs kysten av Norge brukte man fortrinnsvis holmer, øyer, nes, eid, smale sund eller viker med gode kommunikasjonslinjer langs sjøen og med gode landingsforhold. Ørnfløya 1 passer godt i dette bildet.

Lokaliteten lå i sin tid på en slak skråning på lesiden (østsiden) av en liten øy (Ørnfløya, $154 \mathrm{~m}$ ) ut mot det trangeste stedet av et smalt sund som skilte øya fra Kvaløya (figurene 2-4). Den ligger på en smal strandterrasse ca. 22 moh. og ca. $18 \mathrm{~m}$ under marin grense (T. O. Vorren mfl. 2013) og ca. 200 m sør for den nød-utgravde lokaliteten Sandvika 1 (Barlindhaug 1994, 1997; Thuestad 2005). Det finnes ikke noen naturlig havn; man har måttet trekke båten(e) direkte opp over en bratt kant på ca. $1 \mathrm{~m}$ til den lett skrånende terrassen. Lokaliteten ser likevel ut til å ha ligget godt beskyttet mot sundet, da det er flere små holmer rett utenfor. Mot vest vender øya mot Atlanteren, mot vest-nordvest ligger Sommarøy $(55 \mathrm{~m})$ og Hillesøy $(210 \mathrm{~m})$, mot vest-sørvest Brensholmen $(63 \mathrm{~m})$, mot sør den tidligere Brensholmenbukta, halvøya Torsnesaksla (249 m), Malangen med innseilinga til Tromsø

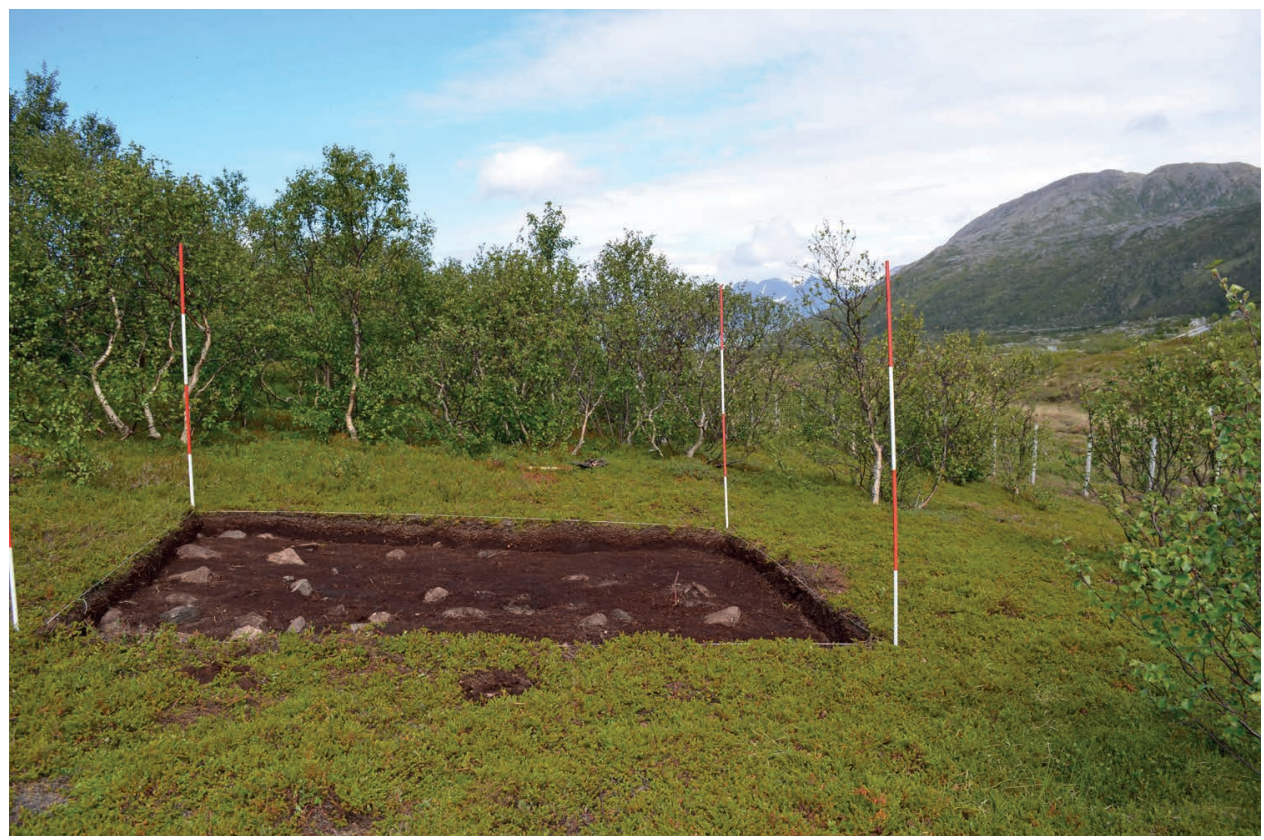

Figur 3. Ørnfløya 1 sett fra sør. (C H.P. Blankholm 2013. 


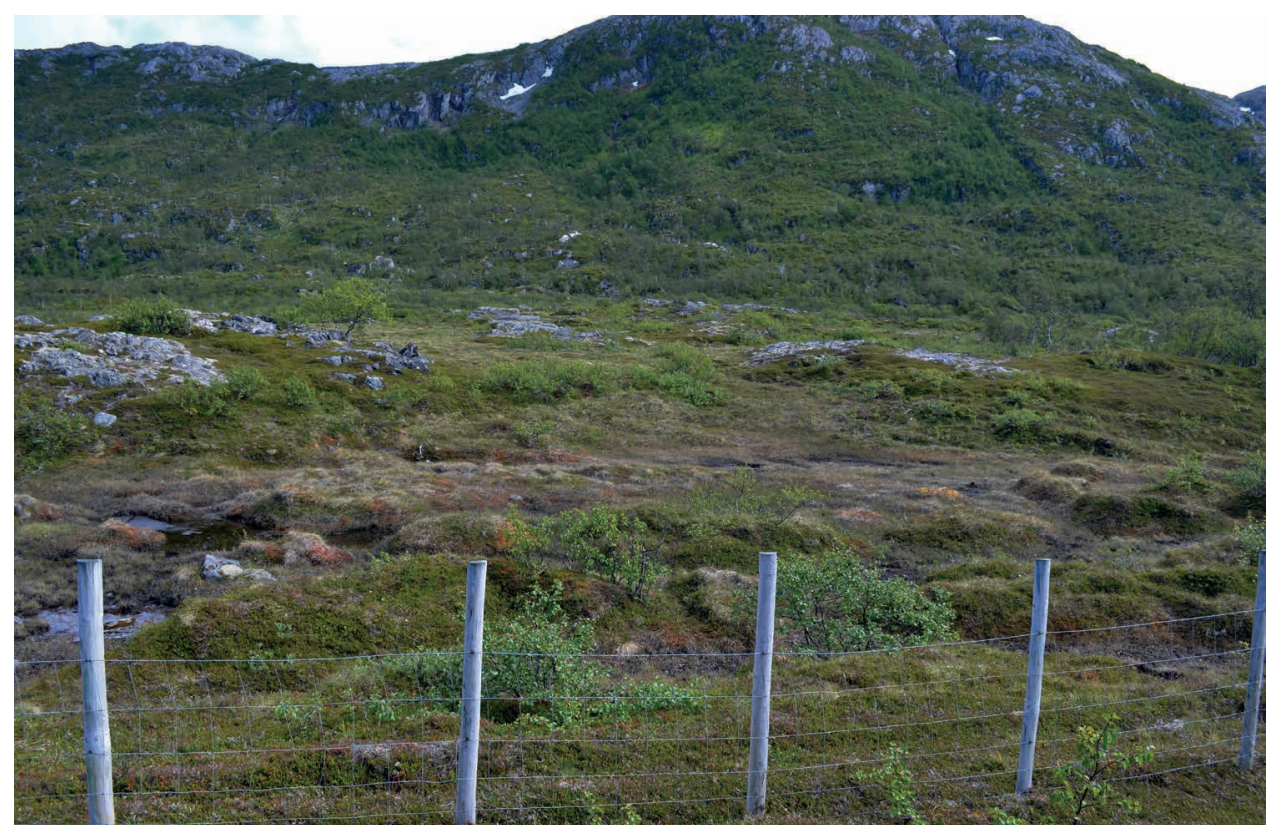

Figur 4. Utsikt fra Ørnfløya 1 over det tidligere sundet. (C) H.P. Blankholm 2013.

og videre mot sørvest-Senja. Mot nordøst har det vært forbindelse fra sundet og inn over Kattfjorden mot det indre av Kvaløya og kanskje også helt til Tromsø gjennom Ersfjorden og Kaldfjorden. Terrenget er, bortsett fra enkelte steile partier på vestkysten, forholdsvis slakt hellende. Det gjelder også de andre ovenfor nevnte øyer og halvøyer i nærområdet. Terrenget på østsiden av det tidligere sundet er derimot steilt, og har høyder på opptil $566 \mathrm{~m}$ (Kvitfjell), og også fjordene inn over Kvaløy er gjennomgående steilt flankert.

Det vi vet om tidligere tiders klima i Troms stammer hovedsakelig fra pollenanalyser og studier av makrofossiler kombinert med C14-dateringer og dendrokronologi. Under det klimatiske optimum i preboreal og boreal tid nådde middeltemperaturen i juli $2,5-3,0{ }^{\circ} \mathrm{C}$ høyere enn dagens gjennomsnittlige ca. $10^{\circ} \mathrm{C}$. Inn mot overgangen fra boreal til atlantisk tid sank imidlertid temperaturen gradvis med minst $1,5^{\circ} \mathrm{C}$ til omkring $1,0-1,5^{\circ}$ høyere enn dagens juli-gjennomsnitt (K. D. Vorren mfl. 1996). En senere studie (Fimreite mfl. 2001) gir et litt mer detaljert bilde av situasjonen i preboreal tid i Midt-Troms. Etter en innledende varm periode med etablering av bjørk omkring $9500 \mathrm{f}$.Kr. ble klimaet kjøligere frem mot ca. $9100 \mathrm{f} . K r$. Denne tiden ble fulgt av et varmere intervall til ca. 8700 f.Kr., etterfulgt av en igjen kjøligere periode frem mot ca. 8400 f.Kr. En studie av bunntemperaturen i den nærliggende Malangsfjorden indikerer at den mellom ca. 6900 og $6400 \mathrm{f} . K r$. var 1,5-3 ${ }^{\circ}$ varmere enn i dag (Husum og Hald 2004). Selv om det er snakk om en strandlinjedatering med de usikkerheter det innebærer, synes Ørnfløya 1, med en datering til ca. 8800 f.Kr. (se nedenfor under datering), altså å ligge i det varme intervallet mellom ca. 9100 og 8700 f.Kr., hvilket trolig har vært ensbetydende med en relativt høyere produksjon av biomasse og derved næringsgrunnlag. 
Den lokale vegetasjonshistorien er godt belyst, men går dessverre ikke tilbake til tidlig etteristid, bare til ca. 4300 f.Kr. (K. D. Vorren 2005), hvilket er langt senere enn det mest sannsynlige tidspunkt for bosetningen på lokaliteten. Tidligere regionale undersøkelser gir imidlertid noen indikasjoner. Før skogen vant frem, bestod vegetasjonen av subarktisk natur med gress, pionerblomster, lyng (Ericaceae) og stander av dvergbjørk (Betula nana) og dvergpil (Salix herbacea / Salix reticulate). Bjørk kom først til ytterkysten ca. 7600 f.Kr. (Mørkved 1991; Fimreite mfl. 2001; Jensen mfl. 2002), og furuskog ble ikke etablert i kystsonen før ca. 5500 f.Kr. og på de ytre øyene ikke før mellom 3800 og 2500 f.Kr. (Mørkved 1991; K.-D. Vorren mfl. 1996; Jensen mfl. 2002). Det var med andre ord et noe karrig landskap som møtte de tidligere beboerne på ytterkysten, men det betyr ikke nødvendigvis dårlig eller utilstrekkelig ressurstilgang.

Det finnes intet konkret om hvilke ressurser som ble utnyttet, men ifølge Helskog (1974) og Blankholm (2008) er det sannsynlig at man blant landressursene har jaktet pattedyr som rein, bjørn, gaupe, jerv, hare, rev og muligens elg, og blant de marine pattedyrene oter, sel og mindre hvalarter. Dette bygger på ovennevnte kunnskap om naturmiljøets sammensetning i Troms i tidligmesolittisk tid. Det er også sannsynlig at fisk som torsk, sei, hyse og kveite var tilgjengelig i likhet med fugl som måke, alke, ender og skarv. I tillegg kommer bær som krekling, blåbær og molte. Lokalitetens beliggenhet kan ikke indikere noe om hva som var mest vesentlig; den ligger som mange andre lokaliteter fra pionertiden sentralt i ekotonsonen mellom land og hav, med lett adgang til begge. Plasseringen ved ytterkysten skulle imidlertid tilsi at det høyst sannsynlig var de marine ressursene som var mest ettertraktet.

To viktige forhold må tas med i betraktningen når man ser på livet i Nord-Norge i tidlig etteristid. Det ene er den lange vinteren med snødekke, som generelt varer fra midten av oktober til midten av mai. Det andre er mørketiden, hvor solen er under horisonten i to måneder mellom midten av november og midten av januar. Med det første følger at mange aktiviteter, innbefattet oppsetting av lette boliger og tilrettelegging av ildsteder, ofte kan ha funnet sted oppå snøen, kanskje flere meter over bakken, gjennom store deler av året. Det gir en ny dimensjon til hvordan det vi oppfatter som boplasser, ble dannet. Alt som ble etterlatt, trenger ikke nødvendigvis å ha blitt deponert direkte på eller i bakken, og bål er det ikke sikkert man finner mange rester av etter at snøen tinet, hvis overhodet noen. Mørketiden har sannsynligvis også hatt stor innvirkning på kommunikasjon, transport, lesing og forståelse av land- og sjøskap (Blankholm 2008).

\section{Utgravning og stratigrafi}

Lokaliteten har Askeladden ID 158925 og Ts. Nr. 12314. Det ble utgravd totalt 29,9 $\mathrm{m}^{2}$ med konvensjonelle metoder og i naturlige lag, og lokaliteten må i praksis anses som totalt utgravd (figur 5). Den er med andre ord ganske liten i utstrekning, med en tilnærmet sirkulær, ca. $6 \mathrm{~m}$ i diameter, fordeling av materiale, typisk for den tidligere pionertids lokaliteter slik de også kjennes på Vestlandet og i Midt-Norge (Breivik og Bjerck 2018).

Stratigrafien bestod av fire lag: underst et grått til hvit-grått lag undergrunnsgrus med mye stein i ulike størrelser (figur 6). Over dette lå kulturlaget - et gulgrått, leirblandet (fettet) og iblant trekullsvertet sandlag rikt på funn - på den opprinnelige vegetasjonsflaten. Tykkelsen varierte generelt mellom 2 og $5 \mathrm{~cm}$, men var enkelte plasser på opptil $12 \mathrm{~cm}$. 


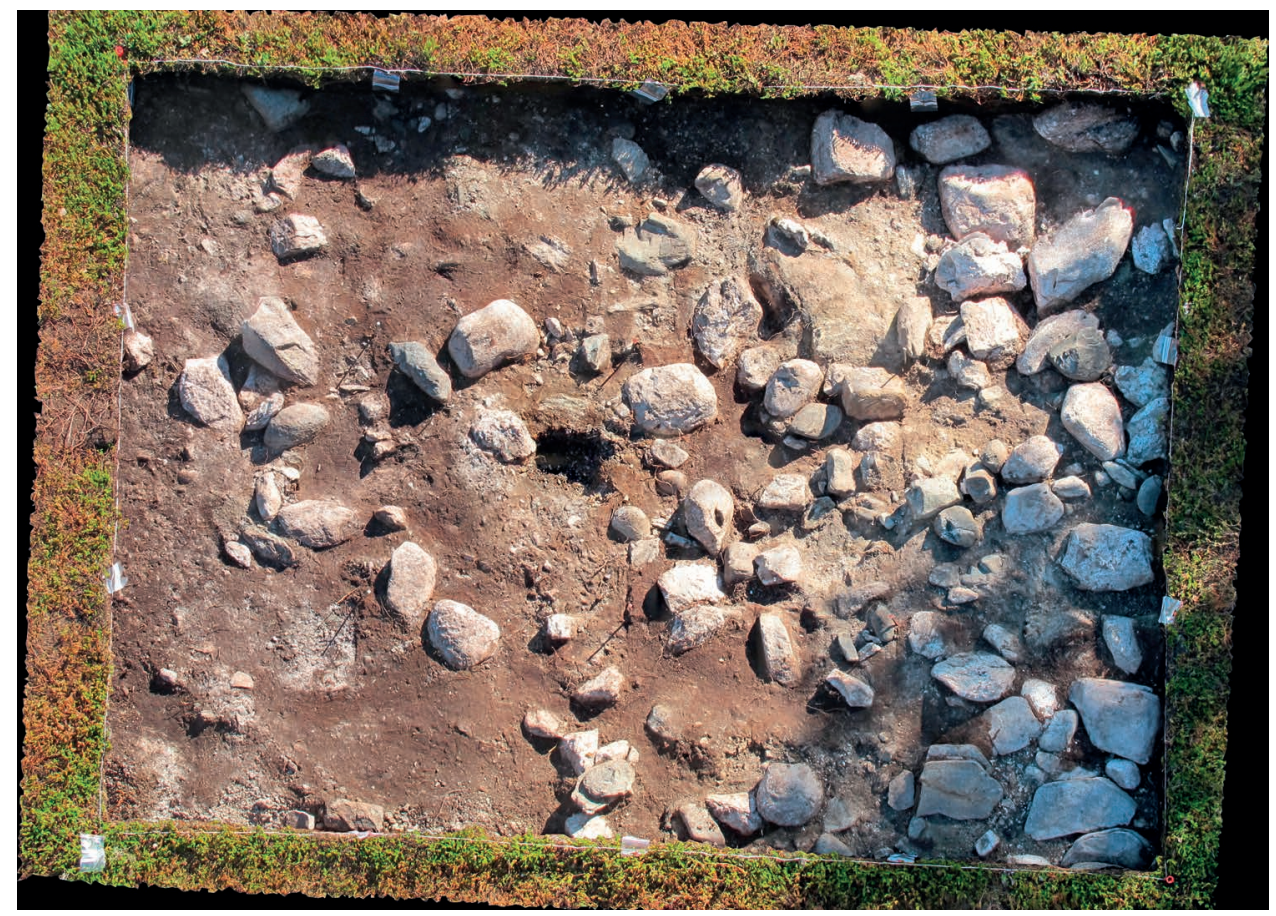

Figur 5. Ørnfløya 1. Loddfoto av utgravningen 2013. Foto Johan Arntzen.

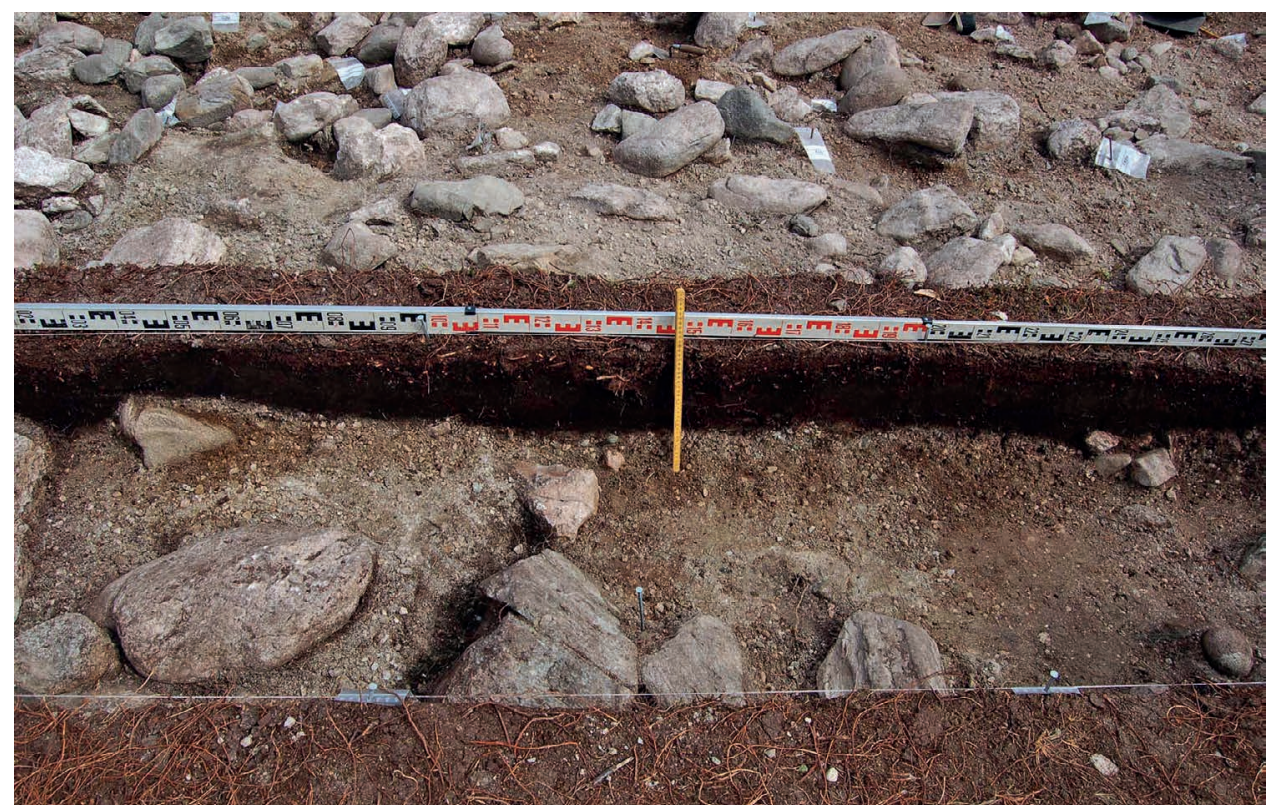

Figur 6. Ørnfløya 1. Et representativt bilde av stratigrafien i den sørligste delen av feltet. 
Kulturlaget var i sin tur dekket av brun, tett og homogen undertorv. Det ble observert til dels store brente og ubrente rester av tre og blader aller nederst i dette laget. Det står i kontrast til kulturlaget, som generelt bare inneholdt små biter av trekull. Øverst lå mørkebrun overtorv.

\section{Datering}

Typologisk hører materialet til Fosna-tradisjonen, og er typisk for pionertiden i tidlig eldre steinalder (Bjerck 2008). En strandlinjedatering i henhold til Møller (1987; Møller og Holmeslett 2012) gir omkring 8800 f.Kr. Med forbehold om usikkerheter generelt knyttet til strandlinjedatering tilsvarer det Bjercks tidligmesolittiske kronosone EM2 (Bjerck 2008; Blankholm 2018a, b). Det var lite trekull bevart. En enkelt prøve fra en liten konsentrasjon i den nordvestlige del av utgravningen ga dateringen $1981 \pm 47 \mathrm{BP}$, kalibrert til tidsrommet 95 f.Kr.-127 e.Kr. (Ua-47368). Dette tilsvarer overgangen fra tidlig metalltid til jernalder, og er dermed klart utenfor den kronologiske rammen den materielle kulturen skulle tilsi. Det samme gjelder for den nærliggende pionertidslokaliteten Sandvika 1, hvor to dateringer angir tidsrommet mellom sen tidlig metalltid og slutten av eldre jernalder (Barlindhaug 1994, 1997; Thuestad 2005). Det har vært mye tidlig metalltids-aktivitet i nærområdet, for eksempel ved Grindvollen hus 4 med flere faser, datert til henholdsvis 1675-1880 og 38560 f.Kr. (TRa-1974-80) (Blankholm 2009) og Sandvika datert til 1400-210 f.Kr. (Jensen og Arntzen 2016), sistnevnte av norrøn art. Det kan derfor ikke utelukkes at ovennevnte brente og ubrente rester av tre og blader er spor etter rydning i den perioden. Dette vil imidlertid også kunne tolkes som at Ørnfløya 1 har ligget vegetasjonsløs og/eller åpen for vær, vind og aktiviteter meget lenge etter at den ble forlatt, slik vi ser det på mange plasser i Finnmark den dag i dag (Blankholm 2018a, b), med derav følgende mulighet for «forurensning» fra senere tiders bruk av området. Alt tyder imidlertid på at Ørnfløya 1 er en kulturell og kronologisk homogen enhet.

\section{Råstoff}

Et av kjennetegnene for pionertiden i Nord-Norge er bruken av en bred serie av steinråstoff, og Ørnfløya 1 bekrefter det (for eksempel Sandmo 1986; Hesjedal mfl. 1996; Barlindhaug 1997; Blankholm 2004, 2008, 2018b; Grydeland og Arntzen 2010; Skandfer mfl. 2010; Hood og Kjellman 2012; Gjerde og Hole 2013; Nergaard og Oppvang 2013). Sandmo (1986) har foreslått at variasjonen kan skyldes at man har forsøkt seg frem med bruken av nye og ukjente råstoff, men den kan like gjerne være uttrykk for ulike kombinasjoner av vedlikehold og ekspedient adferd (Blankholm 2008, 2018b).

Det ble funnet 15 typer råstoff på Ørnfløya 1 (tabell 1). De synes alle, med unntak av sort og gråsort chert, å være jevnt over tilgjengelige i regionen, inklusive Bardu-Målselvvassdraget, enten som lag i fjell, i morener eller på gamle strandvoller. Klassifikasjonen må imidlertid tas med en klype salt. Variasjonen innenfor og mellom de ulike kategoriene er betydelig, slik det også var tilfelle på Målsnes 1 med dens 21 kategorier (Blankholm 2008:34). Ørnfløya 1 og Målsnes 1 har 13 kategorier til felles; to av kategoriene (blågrå, spettet kvartsitt og flint) fantes ikke på Målsnes 1, og åtte kategorier fra Målsnes 1 fantes ikke på Ørnfløya 1. Til sammenlikning har Sandvika 117 forskjellige råstoff representert (Thuestad 2005). Bare fem typer råstoff er felles med Ørnfløya 1, blant dem den sorte cherten og flint. På Sandvika 1 er flinten imidlertid oppdelt i fire undertyper, hvorav kun lysegrå til mørkegrå flint synes å stemme overens med flinten på Ørnfløya 1, mens den tredje hyp- 
Tabell 1. Ørnfløya 1. Oversikt over oldsaker etter råstoff.

\begin{tabular}{|l|l|l|l|l|l|l|l|l|l|l|l|l|}
\hline $\begin{array}{l}\text { Råstoffl } \\
\text { Type }\end{array}$ & Piler & Skraper & Stikler & $\begin{array}{l}\text { Stikkel- } \\
\text { avslag }\end{array}$ & $\begin{array}{l}\text { Stk. med } \\
\text { retusj }\end{array}$ & $\begin{array}{l}\text { Forarb.I } \\
\text { emner }\end{array}$ & Flekker & $\begin{array}{l}\text { Mikro- } \\
\text { flekker }\end{array}$ & $\begin{array}{l}\text { Avslag } \\
(\%)\end{array}$ & Kjerner & $\begin{array}{l}\text { Kjerne- } \\
\text { avslag }\end{array}$ & $\begin{array}{l}\text { Total } \\
(\%)\end{array}$ \\
\hline BGF & 2 & 1 & 1 & & & & 3 & 1 & $97(4)$ & & & $105(4)$ \\
\hline BK & & & & & & & & & $64(3)$ & & & $64(3)$ \\
\hline BSK & & & & & & & & & $49(2)$ & & & $49(2)$ \\
\hline Flint & & & & & & & & & $15(1)$ & & & $15(1)$ \\
\hline GC & & & 2 & & & & & & $78(3)$ & & 1 & $81(3)$ \\
\hline GFK & & 2 & & & & & 2 & & $64(3)$ & 3 & 1 & $72(3)$ \\
\hline GSK & & 1 & 2 & & & & & & $173(8)$ & & & $176(8)$ \\
\hline HGSK & & & & & & & & & $47(2)$ & & 1 & $48(2)$ \\
\hline HGST & & 1 & & & & & & & $66(3)$ & 3 & & $70(3)$ \\
\hline HKK & & 1 & 2 & & & & 2 & & $1076(47)$ & 10 & & $1091(46)$ \\
\hline LGK & & & & & & & 2 & & $81(3)$ & 1 & 1 & $85(4)$ \\
\hline LGSK & 1 & & & 1 & & & 1 & 1 & $187(8)$ & 1 & & $192(8)$ \\
\hline LSK & & & & & & & 1 & & $41(2)$ & 4 & & $46(2)$ \\
\hline MSK & & & 1 & & 1 & & & & $25(1)$ & & & $27(1)$ \\
\hline SC & 1 & & 1 & 1 & 1 & 1 & 5 & & $210(9)$ & & & $220(9)$ \\
\hline Ubest. & & & & & & & 1 & & $17(1)$ & 1 & & $19(1)$ \\
\hline Total & 4 & 6 & 9 & 2 & 2 & 1 & 17 & 2 & 2290 & 23 & 4 & 2360 \\
$(100)$ & $(100)$ \\
\hline
\end{tabular}

BGF = brungrå finkornet kvartsitt, BK = bergkrystall, BSK = blågrå spettet kvartsitt, Flint = flint, GC = gråsort chert, GFK = grå finkornet kvartsitt, GSK = grå stripet kvartsitt, HGSK = hvit/grå spettet kvartsitt, HGST = hvit/grå stripet kvartsitt, HK = hvit kvarts, LGK = lys grå kvartsitt,

LGSK = lys grå stripet kvartsitt, LSK = lys stripet kvartsitt, MSK = mørk stripet kvartsitt, SC = sort chert. Prosent i parentes .

pigst forekommende typen - grov grå helgelandsflint - ikke forekommer på sistnevnte. Det samme gjelden den hyppigst forekommende sorten - en ikke nærmere geologisk bestemt finkornet, grønnlig sandsteinsliknende bergart (Thuestad 2005). Det er vanskelig å si hva man skal legge i dette, ut over vedlikehold og ekspedient atferd samt muligens personlige preferanser og mulig lokal variasjon i tilgjengelighet (se også nedenfor og Blankholm 2018b). Felles for alle tre plasser er imidlertid tendensen til å ha brukt finkornet råstoff av høy kvalitet (som sort og gråsort chert, brungrå finkornet kvartsitt, grå finkornet kvartsitt eller flint) til redskaper som for eksempel piler, skraper og stikler, men disse trenger ikke nødvendigvis å ha vært produsert på lokalitetene. Det synes i alle fall ikke å foreligge produksjonsavfall fra slikt, bortsett fra to primære stikkelavslag på Ørnfløya 1. Det som er interessant med hensyn til råstoffbruk (vurdert etter antall avslag, ikke vekt), ut over at man 
på begge lokaliteter har vektlagt finkornete kvartsitter og cherter, er at man på Ørnfløya $1 \mathrm{i}$ særlig grad synes å ha hugget og benyttet seg av hvit kvarts og ofte av det som oppfattes som middels eller dårlig (uren) kvalitet. Det er det mest dominerende materialet på plassen. Det egner seg sjelden til presisjonsarbeid, for eksempel til tilvirkning av redskaper som piler, men er et eminent og ofte oversett ad hoc materiale til å lage brukbare redskaper man trenger å ha raskt for hånden. Materialet er vidt utbredt, og ved å knuse et større stykke eller med bare noen få slag kan man fort skaffe seg brukbare redskap. Den store forekomsten av hvit kvarts på Ørnfløya 1 kan med andre ord tolkes i retning av en stor grad av ekspedient atferd i den betydningen at man ved umiddelbart behov har tatt noe fra en lokalt lett tilgjengelig åre i mangel av noe bedre. Det finnes godt med kvarts ved lokaliteten, i årer på de små holmene i det tidligere sundet. På den annen side kan det ikke utelukkes at man med kunnskap om disse bevisst har gått for akkurat å bruke den rikelige kvartsen når man planla besøk, og dermed har spart på annet råstoff (se også nedenfor).

\section{Oldsakene}

Med sitt noe grove teknologiske preg er oldsaksmaterialet, som nevnt, typisk for den tidlige pionertids Fosna-tradisjon (se Bjerck 2008; Blankholm 2008). Hele funnet omfatter totalt 2360 oldsaker, hvorav redskaper utgjør $1 \%$, biprodukt $1 \%$ og avfall $98 \%$. Alle oldsaker og deres fordeling på råstoff fremgår av tabell 1. Den romlige fordelingen fremgår av figurene $8-9$.

Det har ikke vært tidsmessig eller økonomisk mulig å foreta slitesporsundersøkelser, chaîne opératoire, eller andre dyptgående teknologiske undersøkelser. En kort gjennomgang viser følgende:

\section{Redskaper}

Spisser. Det ble funnet fire tangespisser; alle i finkornet materiale av høy kvalitet. Akkurat som på Målsnes 1 forekommer de i to størrelsesgrupper (Blankholm 2008:37). En er stor (>25 mm lang), mens resten er små, 15-17 mm lange. Størrelsesforskjellen beror muligens på at man har fremstilt ulike størrelser til jakt på forskjellig vilt (figur 7).

Skraper omfatter i alt seks stykker fordelt med fire i finkornete og to i grovere bergarter. Alle er kraftige avslagsskrapere med tidstypisk steil retusj. Tre er sirkulære, blant de andre tre har to retusj på distalenden og én på proksimalenden. Størrelsen varierer fra $26 \times 32$ x 17 mm til 47 x 42 x 19 mm (figur 7).

Stikler omfatter i alt ni stykker fordelt på syv i finkornete og to i en grovere bergart. Seks er proksimale kantstikler, én er en distal kantstikkel og de to resterende er henholdsvis en midtstikkel og en kraftig tverrstikkel. Størrelsen varierer mellom 24 x 11 x 4 mm og 53 x 21 x $16 \mathrm{~mm}$ (figur 7).

Stykker med retusj. Det ble funnet to stykker med retusj, begge i finkornet bergart. Den ene er et lite avslag på 17 x 10 x 4 mm i sort chert med halvmåneformet retusj, muligens et forarbeid til en pil. Den andre er et lite avslag på 18 x 22 x 5 mm med rett, tverrgående retusj, nesten trunkering, over distalenden.

Emner. Det ble funnet ett emne i sort chert. Det er et rektangulært stykke på $25 \times 18 \times 7 \mathrm{~mm}$, avbrutt i begge ender og med tildannede (retusjerte) sidekanter. Fra begge sidekanter er det gjort forsøk på flatehugging av sideflatene. Funksjonen er uviss. 


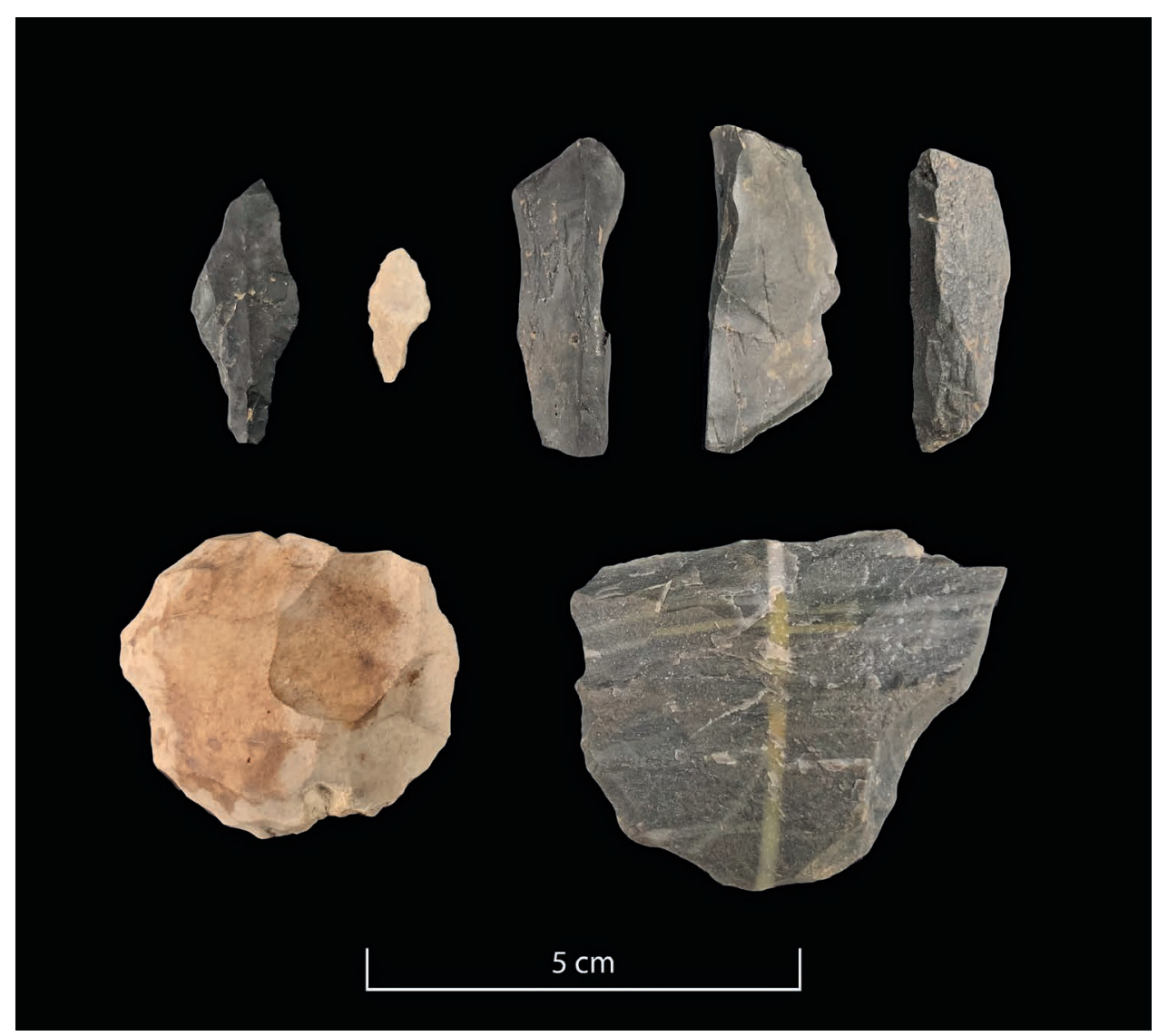

Figur 7. Ørnfløya 1. Utvalg av spisser, skraper og stikler. Foto: Johan Arntzen.

\section{Biprodukt}

Stikkelavslag. Det ble funnet to primære stikkelavslag i finkornet bergart, henholdsvis $32 \times 9 \times 5 \mathrm{~mm}$ og $28 \times 11 \times 6 \mathrm{~mm}$ store.

Kjerner omfatter en noe heterogen, om enn tidstypisk, gruppe på 23 stykker. Det finnes alt fra en akkurat påbegynt stor kjerne på 123 x 86 x $79 \mathrm{~mm}$ til en liten, helt oppbrukt på 30 x 31 × $20 \mathrm{~mm}$. 14 har en plattform, seks har to motstilte plattformer, fem har to plattformer i vinkel på hverandre, to har tre plattformer, og to er bipolare. Det synes ikke å være noen sammenheng mellom antall plattformer og råstoff. Syv kjerner har korteks, herav seks på råstoff av mellomkornet (middels) kvalitet, hvilket kunne tyde på at det spesielt var slikt som ble innsamlet og tilhugget på plassen. Syv kjerner virker totalt oppbrukte, men nøysomheten synes ikke å være rettet mot noe bestemt råstoff. Både hvit kvarts og grå finkornet kvartsitt er representert i gruppa, men sistnevnte med tre eksemplarer og derfor tilsynelatende et råstoff man særlig ønsket å «spare på». Det er interessant at bare fire kjerner av 23 (én er i ubestemt råstoff) er av finkornet materiale. At hvit kvarts er representert med hele 10 kjerner, tilsvarer nok på sett og vis den dominerende mengden av avslag, men at for 
eksempel sort chert - den nest største forekomsten - ikke er til stede, kan tyde på en viss selektivitet, hvor man har tatt med seg «kostbart» materiale videre.

Kjerneavslag omfatter tre kantavslag og ett sideavslag. Råstoffene tilsvarer de som kjennes fra kjernene, med unntak av to: ett i gråsort chert og et i hvit/grå-stripet kvartsitt. Kjerner av sistnevnte to materialer må altså ha blitt hugd på lokaliteten, men ikke gjenfunnet ved utgravningen. De må da enten ha blitt med videre (og gråsort chert ville som et særlig bra materiale nok ha vært kandidat til det), men de kan også ha blitt kastet ut i periferien av selve lokaliteten, et ikke ukjent fenomen for større ting.

\section{Flekker og avslag}

Flekker og avslag (98 \% av materialet) har et typisk pionertidspreg med en noe grov, direkte slagteknikk (Bjerck 2008; Blankholm 2008). De få flekkene er alle irregulære, og bare to kan med god vilje kalles mikroflekker. De svarer sannsynligvis til kriteriene ved tilfeldigheter.

Av 16 flekker er 11 av finkornet råstoff av høy kvalitet. Man har åpenbart bestrebet seg på å gå mer omhyggelig til verks med dem, med henblikk på umiddelbar bruk eller senere, videre forarbeidning.

Av 2360 avslag domineres materialet av 1076 stykker hvit kvarts etterfulgt av 210 stykker sort chert og 187 stykker lysegrå, stripet, finkornet kvartsitt. Slår man sammen gråstripet, finkornet kvartsitt med sistnevnte (overgangen er glidende), kommer disse på andreplass med 360 stykker. Det er altså snakk om et nokså sammensatt bilde. Bruk av varierende mengder kvarts under pionertiden i Nord-Norge er utbredt (Blankholm 2018a). Det som imidlertid setter sitt preg på bruken av kvarts på Ørnfløya 1, er den som nevnt noe ukresne måten man har prøvd seg på å anvende selv meget urent materiale. Dette kan som sagt tolkes som uttrykk for ekspedient atferd, og at man muligens ikke hadde planlagt å bli lenge på det som kan tolkes som en spesialisert sommerfangstplass. Alternativt er det fullt mulig at man ut fra kunnskapen om tilgang på råstoff og med de nødvendige ferdighetene til å håndtere det på stedet, bevisst har gått inn for primært å bruke kvarts under oppholdet (Knutsson mfl. 2016). Hvis det siste var tilfelle, skulle man imidlertid forvente at de hadde vært i stand til også å velge kvarts av sannsynlig bedre kvalitet fra nærområdet.

\section{En mulig bolig}

Et aspekt av funnfordelingen kan tolkes som restene av en mulig boligkonstruksjon på plassen. Det ble hverken funnet stolpehull eller spor av andre nedgravde deler av strukturer på plassen som kunne bidra til å belyse innredningen og aktivitetene der. Det ble heller ikke funnet spor av ildsted. De få (14) ildskjørnede gjenstandene bidrar ikke til å indikere hvor et slikt kan ha ligget, selv om ca. halvparten av dem ligger i området ved veggens (se nedenfor) sørvestlige del. Lodd-fotoet fra utgravingen i 2013 (figur 5) viser heller ikke tegn til et ildsted, og om de ca. 2/3 av flaten mot øst kan betraktes som ryddet, er et åpent spørsmål.

Fordelingen av kjerner er imidlertid interessant. På figur 8 sees en oval utlinje på ca. 2,4 x 1,6 m orientert nordvest-sørøst sentralt i utgravningen, en fordeling ikke ulik de som for eksempel finnes på bl.a. Hamna i Norge, som måler ca. 6,7 x 4 m (Grydeland og Arntzen 2010; Blankholm 2018b), og på Barmose 1 i Danmark, hvor de ofte er blitt tolket som konturen av en bolig (Blankholm 1991, 2018b). Man har ganske enkelt i sin tid enten kastet 
kjernene mot veggen etter endt arbeid, eller senere ryddet dem dit for å bli kvitt større, skarpe gjenstander der man skulle ferdes eller sitte. På Ørnfløya 1 ligger bare få av kjernene bortenfor ovalen.

I en diskusjon av tidligmesolitikums boliger (Fretheim mfl. 2018:217) skriver forfatterne at ambivalens er vanlig i våre tolkninger av periodens boliger, at tvilen ofte ender i positiv retning, men at de oftere tolkes som mulige. I noen tilfeller synes tolkningene å ha vært i overkant liberale, og en mer konservativ tolkning kunne ha vært en god mulighet. I det lyset må konfigurasjonen av kjernene på Ørnfløya 1 nok sees som indikasjon på en mulig bolig, sannsynligvis et telt. Silje Fretheim mfl. fremhever videre at «(..,) these disorderly, indistinct and context dependent dwelling features are, in fact, characteristic of the highly mobile EM lifestyle» (Fretheim mfl. 2018:218). Dette kan det nok være noe i, men på den annen side kan det jo spørres om det ikke er akkurat den ovennevnte ambivalensen og tolkningsnonsjalansen som bidrar mye til variasjonen? Når det er sagt, kan det være god grunn til å holde et våkent øye med tegn på et repetitivt mønster, og det er i det perspektivet man nok bør se Ørnfløya 1. Tilkomsten av 14 halvt nedgravde tufter, åtte teltringer og 14 vindskjul under rekognoseringer på Varangerhalvøya i 2010 (Blankholm 2018a) bidrar også til ikke alene å heve antallet av kjente boligstrukturer. De bidrar også til ytterligere å belyse variasjonen blant disse, og at boliger ikke er så sjeldne som man til nå har trodd, selv om antall lokaliteter uten boligstrukturer fremdeles ser ut til langt å overstige de som har.

Det ble som nevnt ikke funnet noe ildsted, og antallet og spredningen av ildskjørnet materiale gir ikke noen indikasjon på utstrakt bruk av ild. Det fantes bare syv stykker spredt over golvet og en tilsvarende mengde spredt utenfor det sannsynlige inngangspartiet mot sør-sørvest.

I forbindelse med utgravningen ble det foretatt phytolittanalyser, som bredt er studiet av makrofossiler av planter (Neumann mfl. 2017). Det ble tatt ut 15 prøver (herav to kontrollprøver ca. $20 \mathrm{~m}$ bortfor lokaliteten) for å se om det kunne gi en dypere innsikt i (bruken av) vegetasjonen (Zurro 2010, 2014). Undersøkelsene viste a) at dicots (vekster med to blader) fra treliknende vekster kun finnes innenfor selve det utgravde området, og b) at disse er særlig konsentrert i området sør-sørvest for den mulige boligen. En nærmere artsbestemmelse var ikke mulig. Det vil si at konsentrasjonen stemmer overens med det generelle aktivitetsområdet utenfor inngangen til den mulige boligen (se nedenfor), men det er uvisst om det dreier seg om underlag eller noen bestemt aktivitet med tre.

I det følgende skal det sees nærmere på hvordan funnene fordeler seg når det gjelder den mulige boligen.

\section{Romlig fordeling av oldsaker}

Spredningen av redskaper og avfall fremgår av figurene 8-9. Det gjøres oppmerksom på at det bare er punktdata som vises, men utbredelse og frekvenser bekreftes generelt av fordelingen av såldet materiale for hver kategori. Det har ikke vært tidsmessig mulig, og heller ikke av hensyn til plassen i artikkelen, å foreta en regulær kvantitativ analyse av fordelingene (Blankholm 1991, 2008). En intuitiv tolkning av fordelingen viser følgende:

Samlet sett (figur 9) er avslagsmaterialet fra de fleste råstoff i hovedsak konsentrert langsmed det sørlige til sørvestlige og til dels vestlige veggforløpet og utenfor det, mens det 
er relativt mindre materiale på selve golvet, og da generelt på dets sørlige/sørøstlige del. Det mest dominerende materialet på golvet er hvit kvarts, sort chert og gråstripet kvartsitt.

Fordelingen av flekker/mikroflekker er diffus og uten antydning til konsentrasjon. Det er bare få innenfor golvområdet; de fleste andre ligger ut mot periferien fra vest til øst.

Fordelingen av kjerner er allerede omtalt ovenfor; de fire kjerneavslagene er konsentrert omkring den sørlige og sørvestlige delen av veggforløpet, med én på innersiden og tre på yttersiden. De to stikkelavslagene ligger begge utenfor det sørvestlige veggforløpet.

Med hensyn til redskaper er de stort sett fraværende innenfor boligområdet; her finnes bare en spiss, en stikkel og et stykke med forarbeidning. Godt over halvparten finnes i forbindelse med konsentrasjonen av avslag langsmed og utenfor sør-sørvest-veggen, herunder en spiss, to skraper, en stikkel og et stykke med retusj i den tetteste delen av konsentrasjonen rett ved veggen. To skraper, tre stikler og en spiss forekommer spredt langs periferien av golvet fra nordvest over nord til øst.

Det synes ikke umiddelbart å ha vært snakk om flere klart identifiserbare aktivitetsområder med ulike funksjoner. Ut over et generelt funksjonsområde langs veggen mot sør og sørøst og til dels vest og ut fra dette bærer det meste preg av ad hoc-aktiviteter rundt på plassen. På plassen, og særlig på aktivitetsområdet, har man også håndtert materiale fra treliknende vekster (se ovenfor), men uvisst til hvilket formål.

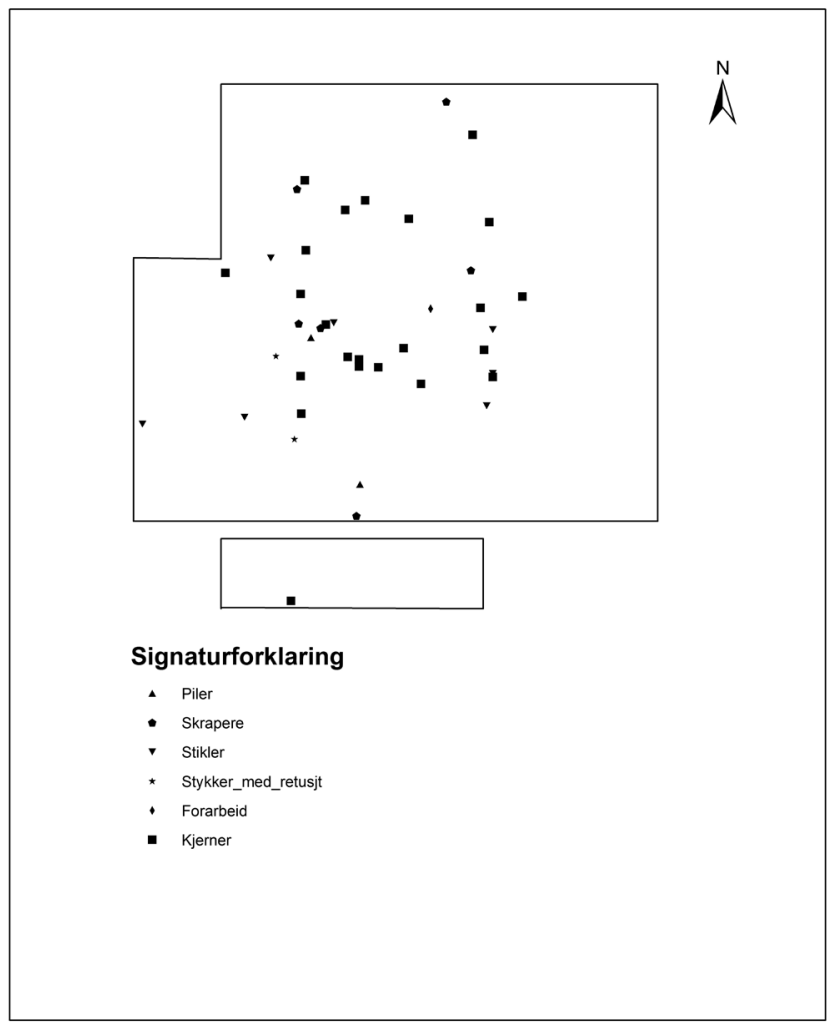

Figur 8. Ørnfløya 1.

Fordeling av redskaper og kjerner. Illustrasjon H.P. Blankholm. 


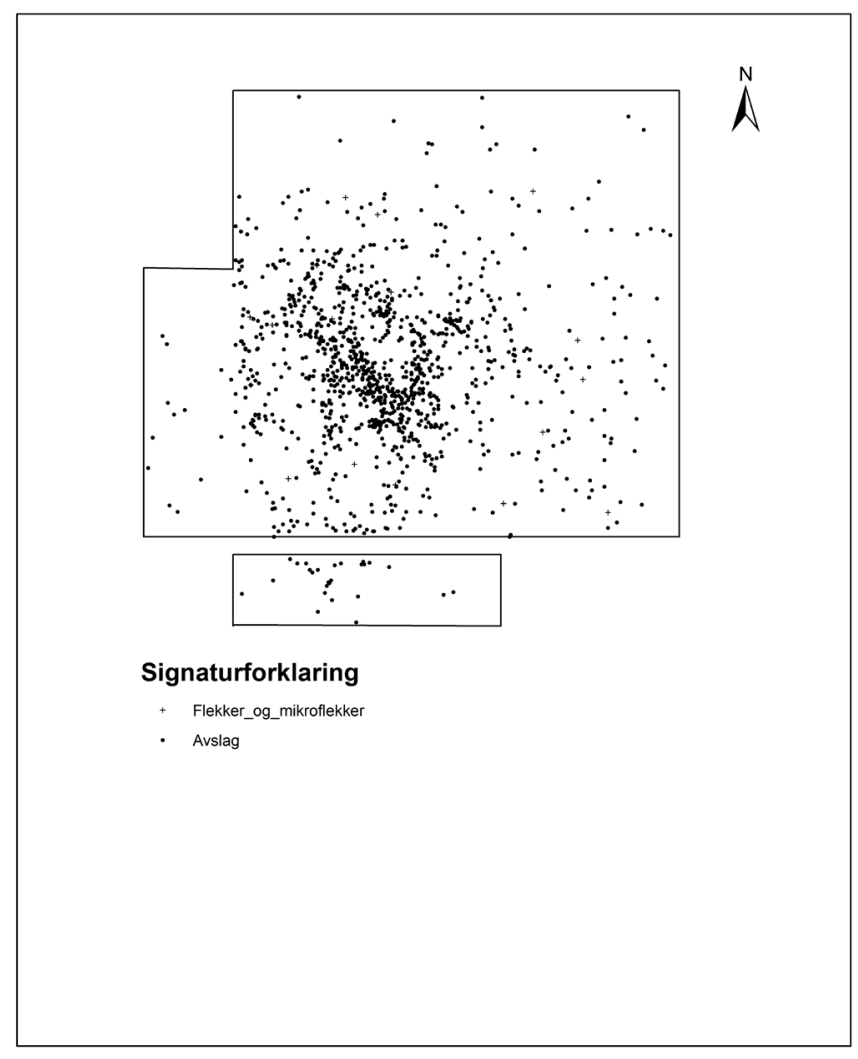

Figur 9. Ørnfløya 1.

Fordeling av flekker og

avslag. Illustrasjon H.P.

Blankholm.

Fastholder man tolkningen av den sentrale, ovale fordelingen av kjerner som et indirekte spor etter en bolig, har åpningen muligvis ligget mot enten øst eller sørøst ut mot sundet, der hvor det også har vært best visuell kontroll med nærområdet. Her er det en åpning i rekken av kjerner og også spor etter aktiviteter utenfor. Det generelle aktivitetsområdet mot sør og sørvest har da ligget skjermet i «solkroken». At den frekvensmessig sterkeste delen av oldsakskonsentrasjonen synes til dels å overlappe det antatte veggforløpet, kan, som antydet ovenfor, enten skyldes at materialet er blitt deponert både inne og ute, men kan også skyldes at materiale som hadde hopet seg opp på den nederste delen av «teltduken», ble omfordelt da den ble fjernet. Det kan heller ikke utelukkes at det har skjedd en viss produksjon etter ankomsten til plassen før man besluttet å reise teltet, og at det derved kom til å overlappe noe med restene fra denne.

\section{Økonomi og bosetning}

Det finnes ikke bevart organisk materiale på plassen, for eksempel, bein, gevir eller tre, som man hadde kunnet bruke til å bestemme økonomi, sesong og funksjon i et bosetningsmønster. Andre forhold på og omkring plassen kan imidlertid gi noen mulige, om enn nokså indirekte, indikasjoner. 
Ovenfor ble det nevnt hvilke dyrearter og vegetabilske ressurser som sannsynligvis var til stede i land- og sjøskapet omkring plassen da den var i bruk. Lokalitetens topografiske beliggenhet kan ikke indikere noe presist om hva som var vesentligst; den ligger som nevnt, og lik de fleste andre lokaliteter fra pionertiden, sentralt i ekotonsonen mellom land og hav, med lett tilgang til begge. Akkurat som Målsnes 1 lå Ørnfløya 1 på den trangeste plassen med det grunneste vannet (det som senere ble toppen av eidet) i et sund med sterkt tidevann. Særlig om sommeren samler seien seg i større stimer med en tendens til å søke mot slike barrierer med sterk strøm og i en dybde på 3-6 m (nåværende tidevannsforskjell er ca. $1,8 \mathrm{~m}$ ) (Blankholm 2008). Kysttorsk ville man hatt mulighet til å fange året rundt; skrei derimot er det sesong for på senvinteren (februar - april). De fleste større sjøfugler er vår- og sommergjester; noen blir, andre trekker videre. Med hensyn til utnyttelse av kjøtt, fjær og egg vil sommeren klart ha vært best. Bær har da, som nå, høyst sannsynlig vært en ressurs for sensommer/tidlig høst.

Tilstedeværelse av boliger er ofte blitt tolket som uttrykk for mer permanent bosetning eller gjenbruk av en boplass og/eller et mer eller mindre eksplisitt uttrykk for vinterbruk (Fretheim mfl. 2018; Gjerde og Skandfer 2018). Forfatteren mener imidlertid at det er høyst tvilsomt om tilstedeværelse eller fravær av boliger uansett størrelse og konstruksjon kan brukes som en sesongindikator (Blankholm 2018b). Investering i arbeidet med jordfaste boliger sier kanskje noe om ønsket om å vende tilbake (gjenbruk), men uten sesongdokumentasjon kommer man ikke nærmere årstiden. Råstoffene gir heller ikke noen direkte indikasjoner på økonomi, sesong eller boplasstype. Selv om man lettest har kunnet skaffe råstoff fra både nært og fjernt om sommeren, eller i det minste etter at snøen har gått, så er de lette å lagre og/eller transportere.

Alt tatt i betraktning synes den mest opplagte sesongen derfor å være sommerhalvåret, kanskje spesielt den mest optimale tiden omkring midsommer.

Ørnfløya 1s lokalitetstype kan ikke fastslås med sikkerhet. Redskapsinventaret kan gi noen indikasjoner, selv om man bør være ytterst varsom med å tolke ut fra tilstedeværelse/ fravær og frekvenser av typer. Sammenliknet med Målsnes 1 (Blankholm 2008), som var vesentlig større (ca. 17 x 8-10 m), som hadde seks distinkte aktivitetsområder (noen med flate sittesteiner) og var omtrentlig fire ganger rikere på oldsaker, så var redskapsprosenten der 2,5\% mot Ørnfløya $1 \mathrm{~s} 1 \%$. Ser man nærmere på redskapene på Ørnfløya 1, er antall piler, skraper og stikler henholdsvis 4, 6 og 9, mot Målsnes 1s 23, 25 og 38. De tilsvarende prosentene for piler, skraper og stikler er henholdsvis 18, 27 og 41 mot Målsnes’ 10, 11 og 17. Samtidig har Målsnes 1 et bredere repertoar med bl.a. skiveøkser, kniver og flekker med makroskopiske slitespor. Ovenstående tall sier imidlertid bare noe om hvor mye som ble tapt eller etterlatt på plassene; ikke noe om hva som opprinnelig ble produsert eller brakt inn, eller hvor lang tid oppholdet varte. Samtidig synes det erfaringsmessig generelt å være en tendens til at typologisk variasjon i oldsaksmaterialer korrelerer positivt med størrelsen på utgravningen og/eller mengden av oldsaksmaterialet (Blankholm 2008). Det eneste som kan tolkes som en viss spesialisering, er den begrensede mengden av redskapstyper og deres gjennomgående høyere prosentandel. Sammenfattet kan Ørnfløya 1 derfor med et visst forbehold tolkes som en spesialisert sommerfangstplass for en, eller noen få, kort(e) periode(r) med en viss grad av ekspedient atferd.

Til sammenlikning ble Målsnes 1 tolket som en relativt liten, midlertidig lokalitet hovedsakelig orientert mot fiske og jakt på marine pattedyr og sannsynligvis brukt over en begren- 
set tid mellom sen vår og tidlig høst (Blankholm 2008). I fall Ørnfløya 1 og Målsnes 1 kan betraktes som samtidige, hvilken type bosetningsmønster inngikk de da i? For Målsnes 1 ble det opprinnelig foreslått fire ulike hypotetiske mønstre plassen kunne ha inngått i (Blankholm 2008:96, oversatt av forfatteren):

1) Et bosetningsmønster med flytninger mellom ytterkysten og innlandet, hvor vintrene ble tilbrakt på kysten, somrene i de (indre) fjordsystemene, midtsommeren langs elver og vann i innlandet (hvis tilgjengelige) og høsten på vei tilbake, med utnyttelse av bærsesongen.

2) Et bosetningsmønster med utnyttelse av ytterkysten og øyene og de (indre) fjordsystemene.

3) Et bosetningsmønster med bruk av ulike typer lokaliteter, ikke langs en kyst-innlandakse, men basert på en forholdsvis kort kystakse inkluderende ytterkysten, større øyer og de ytre og mellomste delene av fjordsystemene.

4) Et langt større system som også involverte tilveiebringelse av råstoff fra fjernere egner, som for eksempel sort chert fra Alta-området.

Det er til nå ikke noen datering fra indre Troms som er eldre enn ca. 6000 f.Kr. (Blankholm 2005, 2008), hvilket foreløpig utelukker alternativ 1. Begge lokaliteter hører imidlertid til blant pionertidsfunnene i Nord-Norge med den karakteristiske sorte cherten, og den må man enten ha reist til det nordlige Kvænangen eller Alta-området - henholdsvis ca. 150 og ca. 300 km borte - for å få tak i, eller man må ha fått den gjennom et handels-, utvekslings- eller «mating»-nettverk (Blankholm 2008, 2018b; White 2017). Det siste vil under alle omstendigheter ha vært en nødvendighet som sikkerhetsnett og for med regelmessige mellomrom å kunne møtes for å utveksle informasjon og finne partnere. Ørnfløya 1 og Målsnes 1 kan derfor utmerket ha vært noder i en kombinasjon av for eksempel alternativ 3 og 4 .

Begge lokaliteter kan ha vært brukt på ulike tider av sommerhalvåret selv om det på det nåværende datagrunnlaget ikke er mulig å si noe konkret om rekkefølgen; muligens har man brukt Ørnfløya 1 før isen ga seg i fjordene og man kunne komme til, for eksempel Målsnes 1 eller det nærliggende Linberget (Blankholm 2008). Det finnes en god del andre lokaliteter fra tidlig eldre steinalder i nærområdet til Ørnfløya 1 og ellers i Tromsø-regionen (se figur 10 og Sandmo 1986, 2011; Barlindhaug 1994, 1997; Grydeland og Arntsen 2010; Skandfer mfl. 2010; Gjerde og Hole 2013; Blankholm 2018b). De er imidlertid med unntak av Simavik, Tønsnes og Bergli enten overflatefunn eller bare utgravd i så beskjedent omfang at det reelt sett bare kan trekkes slutninger om størrelse og topografi samt finnes indikasjoner på oldsaksmaterialenes sammensetning og datering.

Et fellestrekk for alle lokalitetene som ligger helt på yttersida, er at de synes å være ganske små - på størrelse med Ørnfløya 1 og Sandvika 1 og muligens med samme funksjon. Om det betyr at samme gruppe har brukt ulike plasser fra tid til annen, eller om for eksempel ulike grupper har gjort det eventuelt samtidig, er naturligvis vanskelig å si noe om på det foreliggende grunnlaget.

Jan Magne Gjerde og Marianne Skandfer (2018) mener at boplassen Tønsnes kan ha vært en større, sentral samlingsplass brukt om vinteren, en tolkning som ikke minst fremføres på grunn av funnene av store hus. Nå er husene på Tønsnes imidlertid ikke fra tidlig pionertid, og det er ikke undersøkt om forholdene har vært tilsvarende på andre steder i 


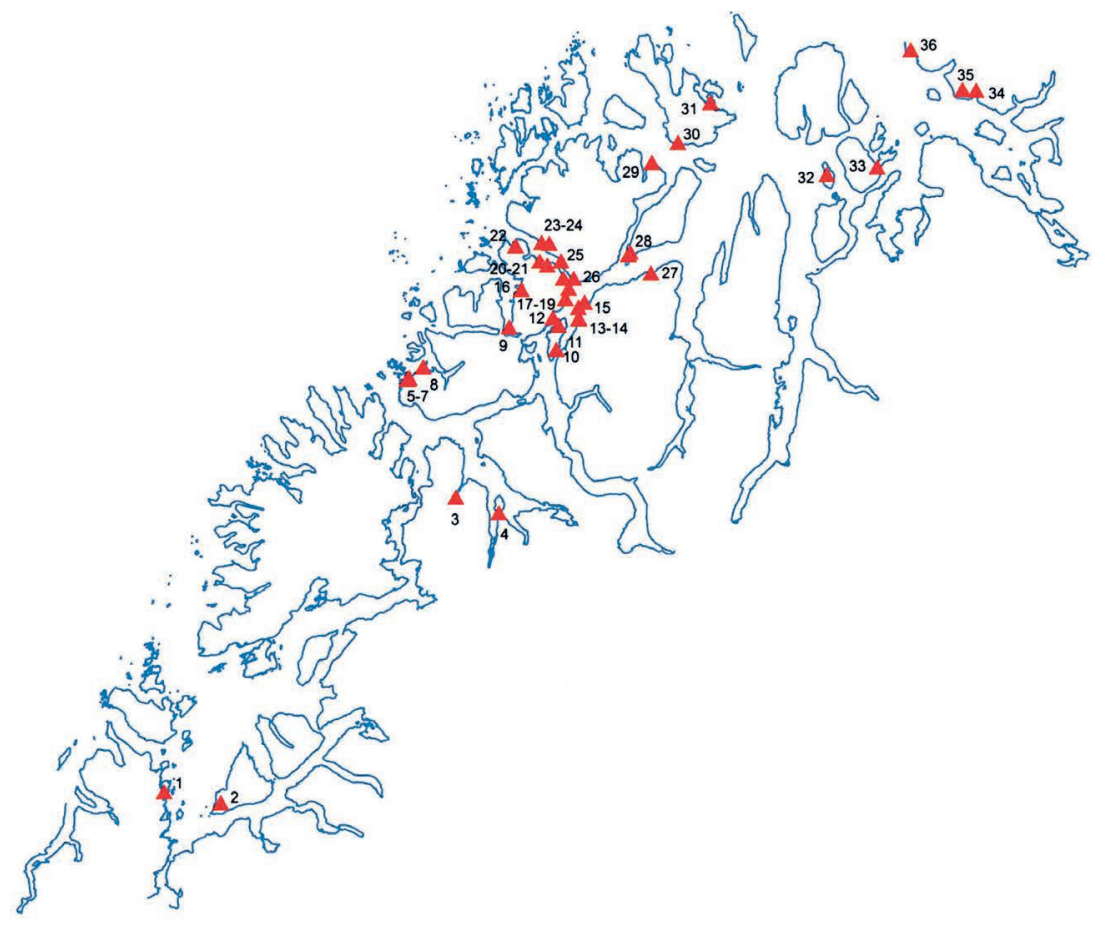

Figur 10. Kart over tidlig eldre steinalderplasser i Troms. 1) Stangnes syd, 2) Sørrollnes, 3) Lindberget, 4) Målsnes 1, 5) Naustvoll, 6) Ørnfløya 1, 7) Sandvika 1, 8) Oldervikeidet, 9) Ekkernes, 10) Mellomveien, 11) Bergli, 12) Lanes, 13) Movika ID-116938, 14) Movika 117000, 15) Tønsnes, 16) Lyfjord, 17) Krabbelv, 18) Kraknes, 19) Futrikelv, 20) Raknes, 21) Rakneskjosen, 22) Høghaugen, 23) Stongnes, 24) Indre Kårvik, 25) Simavik, 26) Storneset, 27) Svarvaren, 28) Finnkrokan, 29) Nord Grunnfjord, 30) Kvalshausen, 31) Lille Skorøya, 32) Vorterøyskagen, 33) Kobbpollen, 34) Reinfjordbotten, 35) Pilvågen, 36) Segelvik. Kart: H.P. Blankholm. Kartgrunnlag: Statens kartverk.

nærregionen med tilsvarende topografi og potensial (Blankholm 2018b). Selv om det utmerket godt kan ha vært tilfelle at folk fra Ørnfløya 1 og/eller Målsnes 1 også benyttet seg av og eventuelt gjenbrukte Tønsnes fra tid til annen, synes det ikke å være noen særlig grunn til å betrakte den som en sentral plass. Slike kan fremdeles ha ligget ved ytterkysten, eller kanskje man slo det hele sammen og dro mot Kvænangen eller Alta for både å hente råstoff og møtes med nettverket sitt (Blankholm 2008)?

Samlet betraktet styrker Ørnfløya 1 på en rekke punkter tidligere oppfatning om hvordan forholdene var på yttersida i Troms i pionertiden, sett i forhold til resten av landet. Den tilhører klart Fosna-tradisjonen og må sees som en del av den tidlige ekspansjonen opp langs Norskekysten (Sandmo 1986; Bjerck 2008; Blankholm 2008, 2018b; Kleppe 2018). Ørn- 
fløya 1 og Sandvika 1 hører også med blant den mest vanlige type lokalitet i pionertiden, hvor ett enkelt (eller kanskje noen få) opphold resulterte i én eller to konsentrasjoner av avfall (Breivik og Bjerck 2018). Rester etter boliger i ulike former fra pionertiden finnes nå også med tiltakende hyppighet (Blankholm 2018a; Fretheim mfl. 2018).

Det er straks vanskeligere å vurdere Ørnfløya 1 og yttersida som sådan når det gjelder økonomi og bosetningsmønster i det regionale og nasjonale perspektivet. For det første har det ikke vært gjennomført noen større og målrettet rekognoseringskampanje i Troms som har kunnet bringe til veie et numerisk representativt materiale fra ulike topografiske soner til å belyse problemstillingene. Modeller som de ovenfor, og også de som er blitt lansert i forbindelse med Tønsnes (Gjerde og Skandfer 2018), er og forblir foreløpig rent hypotetiske. For det andre, og som antydet ovenfor, så sier lokalitetsfrekvenser fra ulike soner, og også sammenlikning mellom regioner på grunnlag av totalt antall lokaliteter (Breivik og Bjerck 2018), i seg selv lite all den stund vi ikke vet med sikkerhet hva eventuelle forskjeller skyldes. De kan i noen områder ha sin årsak i naturlige forhold - for eksempel erosjon/ transgresjon; i andre kan de være antropogent betinget. Et sentralt, men ofte underkommunisert, hvis ikke ignorert, aspekt er imidlertid at bosetningsmønstrene - utnyttelsen av ressurser i (års)tid og rom - kan ha vært nokså ulike. I noen områder kan man ha nøyd seg med noen få lokaliteter, i andre mange. Uten lokaliteter med gode bevaringsforhold for organisk materiale, som for eksempel bein, gevir, tre og lær, samt sesongbestemmelser blir det vanskelig å få dypere innsikt i forholdene.

Det gjenstår med andre ord mye forskning hvis vi skal få større innsikt i pionertidens bosetning slik den utfoldet seg både regionalt og i landet som helhet. Vi trenger ganske enkelt mer dokumentasjon for alle aspekter av livet i pionertiden for bedre å kunne se den i nordnorsk, fennoskandisk og sirkumpolar kontekst.

I denne sammenheng skal vi imidlertid ikke glemme selve menneskene og hva vi kan få ut av å studere skjelettmaterialet (Eriksson og Lidén 2012; Twiss 2012; Schulting 2014; Eriksson mfl. 2016). For en del år siden gikk diskusjonen "Where are the missing boats» (Glørstad 2013 med kommentarer). På samme måte kan man stille spørsmålet «Hvor er menneskene?» Eller rettere sagt restene etter dem. Kanskje det vil være en god idé at vi samtidig som vi søker etter ny og bedre dokumentasjon for boplasser - helst med gode bevaringsforhold for organisk materiale - også begynner å sette fokus på å finne gravene? De omkom vel ikke alle på havet?

\section{Takk}

Det rettes en stor takk til professor Bryan Hood og lektor Johan Arntzen, begge ved Institutt for arkeologi, historie, religionsvitenskap og teologi (AHR), UiT Norges arktiske universitet, samt en anonym reviewer for mange konstruktive forslag til artikkelen. En like stor takk rettes til studiekonsulent Marie Berger Nicolaysen ved AHR for norsk språkvask. 


\section{Litteratur}

Bang-Andersen, Sveinung

2018 The First One Thousand Years: Human Colonization and Differentiated Landscape Use in South-Western Norway, 10.000-9000 BP. I Early Economy and Settlement in Northern Europe. Pioneering, Resource Use, Coping with Change, redigert av H.P. Blankholm, s. 275-310. Equinox, Sheffield.

Barlindhaug, Stine

1994 Rapport fra utgravning av eldre steinalderlokalitet på Brensholmen, Tromsø kommune 1994. Tromsø Museum.

1997 Hvor skal vi bygge og hvor skal vi bo? En analyse avlokaliseringsfaktorer i tidlig eldre steinalder i Troms. Upublisert hovedfagsoppgave i arkeologi. Stensilserie B, Nr. 48. Institutt for arkeologi. Universitetet i Tromsø, Tromsø.

Bjerck, Hein B.

2008 Norwegian Mesolithic Trends: A Review. I Mesolithic Europe, redigert av Geoff Bailey og Penny Spikins, s. 60-106. Cambridge University Press. Cambridge.

Blankholm, Hans Peter

1991 Intrasite Spatial Analyses in Theory and Practice. Aarhus Universitetsforlag, Århus.

2004 Earliest Mesolithic Site in Northern Norway? A reassessment of Sarnes B4. Arctic Anthropology 41:1, 41-57.

2005 Almenningen 1.TS 11174. Utgravning 26.07-20.08 2004. Rapport. Institutt for arkeologi. Universitetet i Tromsø, Tromsø.

2008 Målsnes 1. An Early Post-Glacial Coastal Site in Northern Norway. Oxbow Books, Oxford.

2009 Rapport over prøveutgravning av Grindvollen Tuft 4, 2009. Institutt for arkeologi og sosialantropologi. Universitetet i Tromsø, Tromsø.

2018a Macro-level Predictive Modelling of Early Stone Age Pioneer Settlement Locations in Varanger, Northern Norway. I Early Economy and Settlement in Northern Europe. Pioneering, Resource Use, Coping with Change, redigert av H.P. Blankholm, s. 77-102. Equinox, Sheffield.

$2018 \mathrm{~b}$ Reflections on the Early Mesolithic of Troms, northern Norway, in the light of recent excavations and research. Fennoscandia Archaeologica XXXV:20-33.

Breivik, Heidi M.

2016 Dynamic relations between humans and environment in the earliest settlement phase of Norway (9500-8000 cal. BC). Upublisert doktorgradsavhandling, NTNU, Trondheim.

Breivik, Heidi. M. og Hein B. Bjerck

2018 Early Mesolithic Central Norway: A Review of Research History, Settlements, and Tool Tradition. I Early Economy and Settlement in Northern Europe. Pioneering, Resource Use, Coping with Change, redigert av H.P. Blankholm, s. 169-206. Equinox, Sheffield.

Damlien, Hege og Steinar Solheim

2018 The Pioneer Settlement of Eastern Norway. I Early Economy and Settlement in Northern Europe. Pioneering, Resource Use, Coping with Change, redigert av H.P. Blankholm, s. 335-368. Equinox, Sheffield.

Eriksson, Gunilla, og Kerstin Lidén

2012 Dietary life histories in Stone Age Northern Europe. Journal of Anthropological Archaeology 32:288-302.

Eriksson, Gunilla, Karin Frei, Rachel Howcroft, Sara Gummesson, Fredrik Molin, Kerstin Lidén,

Robert Frei og Fredrik Hallgren

2016 Diet and mobility among Mesolithic hunter-gatherers in Motala (Sweden) - the isotope perspective. Journal of Archaeologcial Science.

Fimreite, Solveig, Karl-Dag Vorren og Tore O. Vorren

2001 Vegetation, climate and ice-front oscillations in the Tromsø area, northern Norway, during the Allerød and Younger Dryas. Boreas 30:89-99. 
Finstad, Ingrid Marie og Sven Erik Grydeland

2009 FV 53 Kroken - Tønsnes, Tromsø kommune. Rapport fra de arkeologiske undersøkelser 2008. Tromura 38.

Fretheim, Silje., Hein B. Bjerck, Heidi M. Breivik og A.F.J. Zangrando

2018 Tent, hut or house? A discussion on Early Mesolithic dwellings proceeding from the site Mohalsen 2012-II, Vega, northern Norway. I Early Economy and Settlement in Northern Europe. Pioneering, Resource Use, Coping with Change, redigert av H.P. Blankholm, s. 207-230. Equinox, Sheffield. Pp. 207-230.

Gjerde, Jan Magne og Johan-Terje Hole

2013 Tønsnes Havn, Tromsø kommune, Troms. Rapport frå dei arkeologiske undersøkingane 2011 og 2012. Tromura 44.

Gjerde, Jan Magne og Marianne Skandfer

2018 Large Mesolithic House-pits at Tønsnes, Coastal Northern Norway: Evidence of a Winter Aggregation Site? I Early Economy and Settlement in Northern Europe. Pioneering, Resource Use, Coping with Change, redigert av H.P. Blankholm, s. 59-76. Equinox, Sheffield.

Glørstad, Håkon

2013 Where are the missing boats? The pioneer settlement of Norway as long-term history. Norwegian Archaeological Review 46:57-80.

Grydeland, Sven Erik og Johan Arntzen

2010 Bergli på Tromsøya: Bosetting fra eldre steinalder og tidlig metalltid. Rapport fra arkeologiske undersøkelser på Bergli, Tromsø kommune, i 2009 og 2010. Tromsø Museums Rapportserie 41.

Helskog, Knut

1974 Stone Age Settlement Patterns in Interior North Norway. Arctic Anthropology 11. Supplement, 266-271

Hesjedal, Anders, Charlotte Damm, Bjørnar Olsen og Inger Storli

1996 Arkeologi på Slettnes. Dokumentasjon av 11.000 års bosetning. Tromsø Museums Skrifter XXVI.

Hood, Bryan C. og Erik Kjellman

2012 Lokalitet 10 (Id. 105042): foreløpig rapport om eldre steinalder boplasser fra Preboreal og Boreal tid. Upublisert rapport. Institutt for arkeologi og sosialantropologi, Universitetet i Tromsø, Tromsø.

Husum, Katrine og Morten Hald

2004 A continuous marine record $8000-1600$ cal. Yr. BP from the Malangenfjord,north Norway: foraminiferal and isotopic evidence. The Holocene 14:6:877-887.

Jensen, Christine og Johan Arntzen

2016. A late Bronze Age sheep farm north of the Arctic circle. I The Agrarian Life of the North 2000 BC $-A D$ 1000, redigert av F. Iversen og H. Peterson, s. 173-201. Portal Books, Kristiansand.

Jensen, Christine, J.G.J. Kuiper og Karl-Dag Vorren

2002 First post-glacial establishment of forest trees: early Holocene vegetation, mollusc settlement and climate dynamics in central Troms, North Norway. Boreas 31:285-301.

Kleppe, Jan Ingolf

2018 The Pioneer Colonization of Northern Norway. I Early Economy and Settlement in Northern Europe. Pioneering, Resource Use, Coping with Change, redigert av H.P. Blankholm, s. 13-58. Equinox, Sheffield.

Knutsson, Helena, Kjel Knutsson, Fredrik Molin og Peter Zetterlund

2016 From flint to quartz: Organization of lithic technology in relation to raw material availability during the pioneer process of Scandinavia. Quaternary International 424:32-57.

Møller, Jakob

1987 Shoreline Relations and Prehistoric Settlement in Northern Norway. Norsk Geografisk Tidsskrift 41. 
Møller, Jakob og Børre H. Holmeslet

2012 Program SEALEV. http://geo.phys.uit.no/sealev/

Mørkved, Brynhild

1991 Når kom skogstrærne til Nord-Norge? Ottar 1991:4:13-19.

Nergaard, Ragnhild H. og Janne Oppvang

2014 Stangnes Syd. Spor etter opphold fra eldre steinalder. Arkeologiske undersøkelser. Rapport.

Tromsø Museum - Universitetsmuseet, Tromsø.

Neumann, Katharina, Alexandre Chevalier og Luc Vrydaghs

2017 Phytoliths in archaeology: recent advances. Vegetation History and Archaeobotany 26:1: 1-3.

Nyland, Astrid J.

2018 Pauler 2 - an ordinary Early Mesolithic site from south-eastern Norway? I Early Economy and Settlement in Northern Europe. Pioneering, Resource Use, Coping with Change, redigert av H.P. Blankholm, s. 369-386. Equinox, Sheffield.

Nærøy, Arne Johan

2015 Utsira - en boplass fra slutten av den vestnorske pionertiden. Viking 2015. s. 7-26.

Sandmo, Anne-Karine

1986 Råstoff og redskap - mer enn teknisk hjelpemiddel. Om symbolfunksjonen som et aspekt ved materiell kultur. Skisse av etableringsforløpet i en nordeuropeisk kystsone 10.000-9000 BP. Upublisert magistergradsavhandling. Institutt for Arkeologi. Universitetet i Tromsø, Tromsø.

Sandmo, Anne-Karine

2011 Kommunedelplan for Sør-Kvaløya, Tromsø kommune. Informasjon om kulturminner og verneverdig bebyggelse. Troms fylkeskommune, Tromsø.

Schulting, Rick

2014. Hunter-Gatherer Diet, Subsistence and Foodways. I The Oxford Handbook of The Archaeology and Anthropology of Hunter-Gatherers, redigert av V. Cummings, P. Jordan og M. Zvelebil, s. $1266-1288$. Oxford University Press. Oxford.

Skandfer, Marianne, S. E. Grydeland, S. Henriksen, R.A. Nilsen og C.R.Valen

2010 Tønsnes Havn, Tromsø kommune, Troms. Rapport fra arkeologiske utgravninger i 2008 og 2009. Tromura 40.

Thuestad, Alma E.

2005 En romlig analyse av tidlig eldre steinalderlokaliteter i Vest-Finnmark og Troms. Upublisert hovedfagsoppgave. Institutt for arkeologi, Universitetet i Tromsø, Tromsø.

Twiss, Katheryn

2012. The Archaeology of Food and Social Diversity. Journal of Archaeological Science 20(4): 357-395.

Vorren, Karl-Dag

2005 Farm development at the Arctic cereal limit in northern Norway - continuity and discontinuities. Vegetation History and Archaeobotany 14: 161-170.

Vorren, Karl-Dag, Torbjørn Alm og Brynhild Mørkved

1996 Holocene pine (Pinus sylvestris L.) and Grey alder (Alnus incana Moench.) immigration and oscillations in central Troms, northern Norway, and their palaeoclimatic implications. Paläoklimaforschung 20:271-292.

Vorren, Tore O., J. Mangerud, L. H. Blikra, A. Nesje og Harald Sveian

2013. The last 11500 years. I The Making of a Land-Geology of Norway, redigert av I.B. Ramberg, I. Bryhni, A. Nøttvet og K. Rangnes, $2^{\text {nd }}$. Edition. Norsk Geologisk Forening, Trondheim.

White, Andrew

2017 A Model-Based Analysis of the Minimum Size of Demographically-Viable Hunter-Gatherer Populations. Journal of Artificial Societies and Social Simulation 20 (4) 9. http://jasss.soc.surrey. ac.uk/20/4/9.html. DOI: 10.18564/jasss.3393. 
Zurro, Debora

2010 Ni carne ni pescado (consumo de recursos vegetales en la Prehistoria): Análisis de la variabilidad de los conjuntos fitolitológicos en contextos cazadores-recolectores. Servicio de Publicaciones de la UAB: http://hdl.handle.net/10803/32145.

Zurro, Debora

2014 Ørnfløya - Photolith analysis. Upublisert rapport. Institutt for arkeologi, historie, religionsvitenskap og teologi. UiT Norges arktiske universitet, Tromsø.

Åstveit, Leif Inge.

2018 The Early Mesolithic of Western Norway. I Early Economy and Settlement in Northern Europe. Pioneering, Resource Use, Coping with Change, redigert av H.P. Blankholm, s. 231-274.

Equinox, Sheffield. 